\title{
Normal Progeny Produced by the Parents Derived from Mouse Eggs Fertilized In Vitro
}

\author{
Kenkichi Kasıi, Masahito Sugmoto and Yutaka ToYoDn \\ School of Veterinary end Animal Sciencea, Kitasato \\ University, Towada-shi 034
}

(Received June 20, 1979)

\begin{abstract}
Abotract Superovulated eggs from $F_{1}$ (C3H/He $\times \mathrm{Cs} 7 \mathrm{BL} / 6 \mathrm{~J}-\mathrm{at} / \mathrm{at}$ ) female mice fertilized in vitro by epididymal sperm of JCL:ICR strain were cultured far $72 \mathrm{hr}$, transferred to the uteri of pseudopregnant recipients and the reproductive capacity of the young born from the recipients was examined by full-sib mating. Fertilization rate was $80.9 \%$ (416/517) as judged from the second polar body extrusion at $6 \mathrm{hr}$ after insemination. The developmental rate of these fertilized eggs to the morula and early blestocyst was $97 \%$ ( $399 / 405)$ after $72 \mathrm{hr}$ in culture under $5 \% \mathrm{CO}_{2}$ in air. Trensferred to the uteri of Day 3 or Day 4 preudopregnant recipients were 245 of these embryos, resulting 29 male and 23 fensele stormal newbom young. Of these young, 7 fernates were randomly selected and mated poiygamoukly within the same litter at 2 to 3 months of age. All females became prognant and delivered 37 males and 42 fomales. No gross anomalies were found among these offspring. Average body weight at 3 weeks of age was $12.2 \pm 2.7 \mathrm{~g}$ for males and $12.3 \pm 1.7 \mathrm{~g}$ for fernales. From these findings, it is suggested that normal progeny can be produced by parents derived from superovulated eggs fertilized in vitro.

Jap. J. Zooteck. Sci, 50 (12): 885-890, 1979
\end{abstract}

The fertilization process has been accomplished in vito in many species of manmaks". Criteria for nomal fertilization, however, have not in most cases included the production of viable young following transfer of the embryos to suitable recipient females. We may conclude at this point that the development of eggs fertilized in vitro into viable young when embryos were transferred to pseudopregnant animals was com-

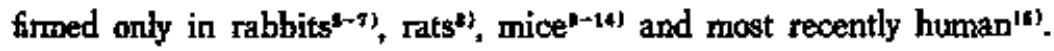

None of the reports, however, have so far clarified the reproductive potentiality of the young derived from eggs fertilized in vitro.

The purpose of this paper is to investigate the reproductive capacity of female and male mice developed from eggs fertilized in vitro.

\section{Materiala and Methods}

1) In vitro fertilization and culture of fertilized eggs

Virgin 2 to 6 months old $\mathrm{F}_{1}$ (C3H/He $\times$ C57BL/6J-at/at) fernales were superovulated by injection of 5 IU PMSG (Peamex, Sankyo Zoki), followed 48 hr later by 5 IU hCG (Puberogen, Sankyo Zoki). Methods and medium for fertilization and subsequent culture in vitro used were as described by KASAT et al."1). The females were killed 15-16 hr after the injection of hCG and their oviducts were removed and put into the 
culture dish (35 $\times 10 \mathrm{~mm}$, Falcon Plastic) containing $0,4 \mathrm{~m} l$ of medium under paraffin oil (Art 7160, Merck) maintained at a temperature of $37^{\circ} \mathrm{C}$ under $5 \% \mathrm{CO}_{4}$ in air. The wall of the ampullar portion of the oviduct was dissected with a needle and the eggs surrounded by cumulus cells were introduced into the medium. Sperm was obtained from the cauda epididymidis of 4 months old JCL:ICR male mice and suspended into $0.4 \mathrm{ml}$ of the mediun under paraffin oil. After preincubation for $1 \mathrm{hr}$ at $37^{\circ} \mathrm{C}$ under $5 \% \mathrm{CO}_{2}$ in air, a small volume of sperm suspension was added to the medium containing eggs with a calibrated glase pipett according to Toyode et al.15). The final sperm concentration was adjusted to $150 \mathrm{cells} / \mu l$ in each experiment. Following incubation for $6 \mathrm{hr}$, eggs which extruded second polar body were picked up from the medism under the dissecting microscope, washed twice and cultured in $0.2 \mathrm{ml}$ droplets of medium under oil for $66 \mathrm{hr}$ (total culture period: $72 \mathrm{hr}$ ). The fertilization rate was calculated by determining the proportion of eggs with second polar body of the total number of eggs examined. The preimplantation development rate was calculated by determining the proportion of cultured embryos which reached the monula and early blastocyst stage after $72 \mathrm{hr}$ in cuthure. After cultivation, embryos to be transplanted were removed from culture dishes, washed once and then transferred to other dishes freshly prepared. These dishes were kept at $37^{\circ} \mathrm{C}$ under $5 \% \mathrm{CO}$, in air until transfer.

\section{2) Transfer of embryos to pseudopregnant mice}

Pseudopregnancy was induced by mating JCL:ICR fernales to sterility tested vasectomized JCL:ICR males in the night following the day of proestrous vaginal smear. Females which displayed continuous diestrous vaginal smear were used for the recipients on Day 3 or Day 4 pseudopregnancy (Day 1 is the day on which the vaginal plug was noticed). After anesthetizing the recipient with $60 \mathrm{mg}$ sodium pentoharbital per $\mathrm{kg}$ body weight and exposing the oviducal end of the uterus through dorsal incision, a short glass rod was passed through the mesometriun in order to hold the uterin hor in place. The cranial end of the uterus was punctured with a 25-gauge needle and through the resulting hole, embryos suspended in - a small amount of medium $(0.5 \mu l)$ were then introduced. This was achieved by using a fine glass pipett attached to a mouth piece. Six to 12 embryos were transplanted per recipient.

The remaining embryos were transferred into the $0.2 \mathrm{ml}$ of culture medium containing colcemid $(0.08 \mathrm{~kg} / \mathrm{ml})$ under paraffin oil, cultured further for a few hours and then examined for their cell numbers by TakKowskn's method '"?

\section{3) Observation of progeny}

The recipients were exarnined daily for their vaginal smears. They were housed individually after a placental sign had been observed and allowed to deliver their young. Sex of the young was determined on the day following delivery. All of them developed normally with the exception of one died during nursing. When they reached 2 to 3 months of age, 7 females from 3 litters born from Day 3 recipients were randomly selected and mated polygamously within the same litter and observed for 
conception and delivery. All young were left with their mothers. Their growth was observed during the nursing period for 3 weeks. Body weight was measured individually at 3 weeks of age.

\section{Resnlts and Discussion}

1) In vito fertilization and development in culture

The percentage of fertilization judged fom the observation of second poiar body extrusion at $6 \mathrm{hr}$ after insemination was 80.9\% (Table 1). Almost all of the eggs judged to be undergoing fertilization developed to the 2-cell stage within $24 \mathrm{hr}$ after insenination $(99.8 \%)$ and most of them (97.5\%) proceeded to the 4-8-cell stage during $48 \mathrm{hr}$ of culture. At the end of the culture period, $72 \mathrm{hr}$ after insemination, $97.0 \%$ (393/405) of eggs developed to the morula and early blastocyst stage. The developmental rate to 4-8-cell stage was similar to our previous results ${ }^{10)}$. The rate of developrnent to morula and early blastocyst, however, was much higher than earlier test results"'). It may have been caused by technical improvements. The developmental rate to the morula and early blastocyst was similar to the results of HOPPE and PITTS ${ }^{(3)}$, in spite of our simple culture condition using a gas phase of $5 \% \mathrm{CO}_{3}$ in air, instead of $5 \% \mathrm{CO}_{2} 5 \% \mathrm{O}_{2}, 90 \% \mathrm{~N}_{2}$. Although the effectiveness of reduced oxygen partial pressure was substantiated for the embryonic development of several mammalian species'1-10, the present result seems to show that the gametes of $F_{1}$ female mice fertilize better in vitro and that more fertilized eggs are capable of developing to the blastocyst stage adapting themselves to the environmental candition during culture than those from inbred or randombred strains.

Table 1. Fertilization and preimplantation derelopment in vitro.

\begin{tabular}{|c|c|c|c|c|c|}
\hline \multirow{2}{*}{$\begin{array}{l}\text { No. of } \\
\text { animals } \\
\text { used }\end{array}$} & \multirow{2}{*}{$\begin{array}{l}\text { No. of ferti- } \\
\text { jized eggs/ } \\
\text { No. of eggs } \\
\text { examined } \\
(\%)\end{array}$} & \multirow{2}{*}{$\begin{array}{l}\text { No. of } \\
\text { eggs } \\
\text { cultured }\end{array}$} & \multicolumn{3}{|c|}{ No. and $(*)$ of eggs developed to } \\
\hline & & & $\begin{array}{c}\text { 2-cell } \\
(2 \mathrm{hr})^{\bullet \prime}\end{array}$ & $\begin{array}{l}4-8 \text {-cell t } \\
(48 \mathrm{hr})^{-1}\end{array}$ & $\begin{array}{c}\text { morule \& early } \\
\text { blastocyst } \\
(72 \mathrm{hr})^{*}\end{array}$ \\
\hline & & 40 & $\begin{array}{l}404 \\
99.8 \%)\end{array}$ & $\begin{array}{c}395 \\
(97.6 \%)\end{array}$ & $\begin{array}{c}393 \\
(97.0 \%)\end{array}$ \\
\hline
\end{tabular}

a) : Culture period.

\section{2) Development of embryos following transfer}

The embryos were composed of a mean cell number of $24.4 \pm 6.73$ (Mean \pm S. D., $\mathrm{n}=88$ ) at the end of culture period for $72-80 \mathrm{hr}$. As shown in Table $2,9 / 10(90 \%)$ recipients which had received the embryos on Day 3 became pregnant and 41 young (34.2\%), 27 males and 14 females were born from 8 recipients. On the other hand, in the case of Day 4 transfer, $5 / 11(46 \%)$ recipients became pregnant and 11 young $(8,8 \%), 2$ males and 9 females were obtained from 5 recipients. A total of $52(21.1 \%)$ offspring, 29 males and 23 fernales were born from 245 embryos transferred to 21 recipients. The difference in conception rate was not significant between Day 3 and 
Table 2. Results of traniplantation of morula and eary blastocyet at days 3 and 4 of pseatopregrant recjpients.

\begin{tabular}{ccccccc}
\hline & $\begin{array}{c}\text { No. of } \\
\text { recipi- } \\
\text { ents } \\
\text { used }\end{array}$ & $\begin{array}{c}\text { No. of } \\
\text { embryos } \\
\text { trans- } \\
\text { ferred }\end{array}$ & $\begin{array}{c}\text { No. of } \\
\text { preg- } \\
\text { nant } \\
\text { animals }\end{array}$ & $\begin{array}{c}\text { No. of ani- } \\
\text { mals which } \\
\text { delivered }\end{array}$ & $\begin{array}{c}\text { No. of } \\
\text { live born }\end{array}$ \\
\hline Day 3 & 10 & 120 & 9 & 8 & $27^{21}$ & $14^{\prime \prime}$ \\
Day 4 & 11 & 125 & 5 & 4 & 2 & 9 \\
\hline
\end{tabular}

a): Sever females and males from the same litter were ued for progeny test (see Table 3).

Day 4 recipients (P>0.05), but the proportion of embryos that developed to newborn young was significantly higher in Day 3 recipients than in Day 4 recipients $(\mathrm{P}<$ 0.01).

The appearance of a placental sign and the duration of pregnancy were $11.0 \pm 0.7$ days and $19.9 \pm 1.2$ days in Day 3 recipients, and $11.0 \pm 0.7$ days and $21.5 \pm 0.6$ days in Day 4 recipients, respectively, The gestation period of Day 4 recipients seerned to be prolonged as compared to the period of Day 3 recipients, but the difference was not significant $(P>0.05)$. Average body weight of the young at 21 days after delivery was $15.0 \pm 2.3$ and $13.4 \pm 1.7 \mathrm{~g}$ in Day 3 and Day 4 recipients, respectively.

3) Reproductive capacity of the young

Seven females, derived from Day 3 recipients and mated to males of the same litter, became pregnant and delivered nornal newborn young. The results are summarized in Table 3 . Thirty seven males and 41 females were obtained from 7 females. The average litter size was 11.1 . There was no gignificant difference between the

Table 3. Average body wejght of progeny produced by the parenta derived from eggs fertilized in vitro.

\begin{tabular}{|c|c|c|c|c|c|c|c|}
\hline \multirow{2}{*}{$\begin{array}{c}\text { Female no. } \\
\text { nsed for } \\
\text { progeny } \\
\text { test" }\end{array}$} & \multicolumn{2}{|c|}{$\begin{array}{l}\text { No. of young } \\
\text { born }\end{array}$} & \multirow{2}{*}{ Total } & \multicolumn{4}{|c|}{$\begin{array}{l}\text { Av. body weight (g) and (ronge) } 21 \text { days } \\
\text { after delivery }\end{array}$} \\
\hline & Male & Female & & No. & Male & No. & Female \\
\hline K-2-1-1 & 5 & 5 & 10 & 5 & $\begin{array}{c}16.08 \pm 0.86^{-1} \\
(14.8 \text { to } 17.2)\end{array}$ & 5 & $\begin{array}{c}14.76 \pm 0.68 \\
(14.0 \text { to } 15.8)\end{array}$ \\
\hline$K-2-1-2$ & 6 & 4 & 10 & 6 & $\begin{array}{l}10.57 \pm 2 . \infty \\
(0.7 \text { to } 14.2)\end{array}$ & 4 & $\begin{array}{l}10.68 \pm 1.26 \\
(9.5 \pm 012.3)\end{array}$ \\
\hline K-S-1-1 & 9 & 4 & 13 & 9 & $\begin{array}{l}10.84 \pm 0.92 \\
(9.6 \text { to } 12.2)\end{array}$ & 4 & $\begin{array}{l}11.48 \pm 0.78 \\
(10.9 \text { to }[3.6)\end{array}$ \\
\hline$K-3-1-2$ & 4 & 9 & 13 & 4 & $\begin{array}{c}12,00 \pm 0,26 \\
(11,7 \text { to } 12,3)\end{array}$ & 9 & $\begin{array}{l}11.96 \pm 0.66 \\
(11.1 \text { to } 13.9)\end{array}$ \\
\hline S-2-5-1 & 4 & 4 & 8 & 4 & $\begin{array}{l}16.15 \pm 1.92 \\
(13.7 \text { to } 18.0)\end{array}$ & 4 & $\begin{array}{c}15.43 \pm 0.66 \\
(14.6 \text { to } 16.2)\end{array}$ \\
\hline $5-2-5-2$ & 5 & 9 & 14 & 5 & $\begin{array}{l}10.2 \pm 2.42 \\
(6.2 \text { to } 12.9)\end{array}$ & 9 & $\begin{array}{l}11.42 \pm 0.79 \\
(10.1 \text { to } 12.3)\end{array}$ \\
\hline$S-2-5-3$ & 4 & 6 & 10 & 4 & $\begin{array}{l}11.4 \pm 0.74 \\
(10.9 \text { to } 12.5)\end{array}$ & 6 & $\begin{array}{l}11.95 \pm 0.62 \\
\text { (11.9 to } 12.8)\end{array}$ \\
\hline
\end{tabular}

a): Alt females were mated to males of the same litter. b): Mean $5 . D$. 
number of female and male young $(P>0.05)$. The average body weight at 21 days after delivery was $12.2 \pm 2.7 \mathrm{~g}$ in males and $12.3 \pm 1.7 \mathrm{~g}$ in females, No gross abnormalities were found among these young.

In the control experiment, 2-cell embryos were collected from the oviducts of mated females, cultured for $48 \mathrm{hr}$ and 24 embryos developed to morula and early blastcyst were transferred to the uterine horns of 2 pseudopregnant recipients. Nine males and 5 females were obtained from the recipients. These young were mated polygamously within the same litter at 2 to 3 months of age. The average litter size was 11.2 $(n=5)$ and average body weight at 3 weeks of age was $12.4 \pm 1.5 \mathrm{~g}$ in male $(n=28)$ and $12.0 \pm 1.5 \mathrm{~g}$ in females $(\mathrm{n}=28)$. There was no significant difference between the experimental and control groups as to litter size and body weight.

The present results show that a normal progeny can be produced by the parents derived from eggs fertilized in vitro. This research has just been started and further studies are being conducted.

The authors wish to express their gratitude to Dr. K. Murakami of Sankyo Zoki Company for the generous gifts of PMSG and hCG, and to Mrs. Hildegard Howert, M. A. for her kindness in reading and revising the manuscript. This study was supported by a grant-in-aid for scientific research No. 248074 from the Ministry of Education, Science and Cujture of Japan, and a grant aided by the Ministry of Health and Welfare of Japan for research on handicapped children.

\section{References}

1) Rogers, B.J., Gamete Res., 1: 165-223. 1978.

2) Chast, M.C., Nature, 184: 466-467, 1959.

3) BracketT, B. G. and G.OuIphas, Biol, Reprod, 12: 260-Z74. 1975.

4) Brackett, B. G., J. A. Mruts and G. G. Jeittes, Fertil. Steril, 23: 898-909. 1972.

5) Fraser, L, R. and P. Y. Danbexar, J. Exp. Zook, 184: 300-312, 1973.

6) Mulz, J.A., G.G. Jejties and B. G. BrackerT, Fertil. Steril., 24: 602-608. 1973.

7) Sejper, G, E., R. A. Bowen and M. T. KAнE, Fertil, Steril., 27: 861-870. 1976.

8) Torona, Y. and M. C. Chang, J. Reprod. Fert, 36: 9-22. 1974,

9) WartrigethM, D.G., Nature, 220: 598-593. 1988.

10) Cross, P.C. and R. L. Briwstex, Biol. Reprod., 3: 298-307, 1970.

11) Muyakoto, H. and M.C.ChkNg, J. Reprod. Fert., 90: 135-137. 1972.

12) MúnerjeE, A. B., Nature, 237; 397-398. 1972.

19) Hopes, P.C, and S. PITTs, Biol, Reprod, B: 420-426. 1973.

14) Mukherjee, A. B. and M.M. Cohen, Nature, $472-473.1970$.

15) Stestoe, P.C. and R.C. Eownros, The Lancent, ii: 366: 1978.

16) Kashi, K., Y. Minato and Y. Tơoos, Japan. J. Anim. Reprod., 24: 19-22. 1978.

17) Toroos, Y., M. Yoxorame and T. Hosj, Japan, J. Anim. Reprod., 16: 147-151. 1971.

18) Tarкowsk, A. K, Cytogenetics, 5: 394-400. 1966.

19) Ausksach, S. and R. L. Burnster, Nature, 217: 465-466. 1968.

20) Qurk, P. and G.M. Haklow, Theriogenology, B: 161. 1977.

21) Tepvit, H. R. D.G. Whitringtuls and L. E. A. Rowson, J. Reprod. Fert., 30; 493-497. 1972.

22) Togvit, H. R. and L, E. A. Rowson, J. Reprod. Fert., 38: 177-179. 19/4.

23) Wugers, R. W. G. B. Andekeon, P.T. Cupps and M. Drost, Bjol. Reprod., 14: I57-162. 1976.

24) Wright, R. W., J. Anim. Sci, 44: 854-855. 1977.

25) Davis, D. L. and B. N. Dny, J. Anim. Sci, 46: 1043-1063. 1978.

๘) Qurk, P. and G. M. Hartow, J. Exp. Zool., 206: 73-80. 1978. 


\section{体外受精に由来するマウス間の交配による 正常糜子につけて}

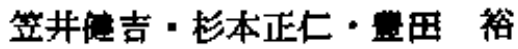

北里大学等医畜産学部，才和田市 034

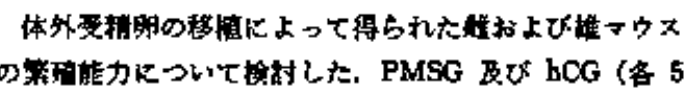

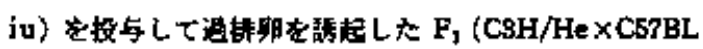

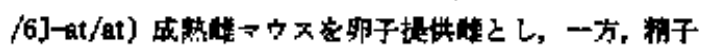

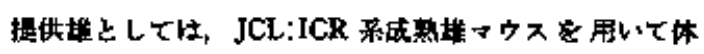

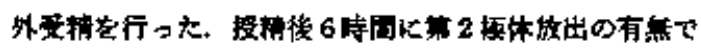

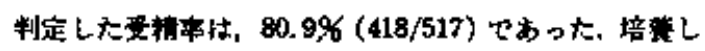

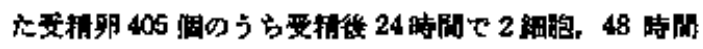

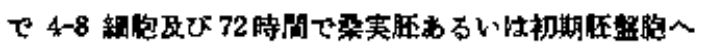
発生したものはそれだれ，99.8\%，97.5\%， 茂び97.0\%

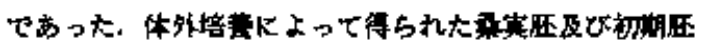

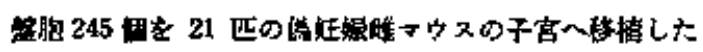

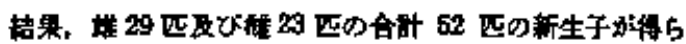

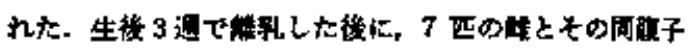

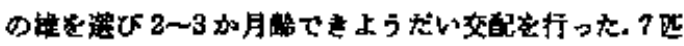

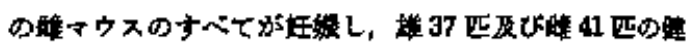

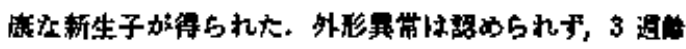

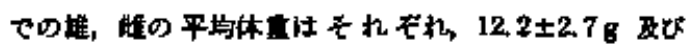

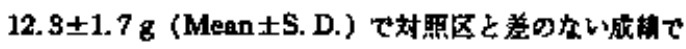

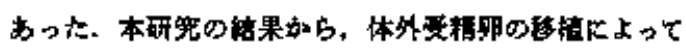

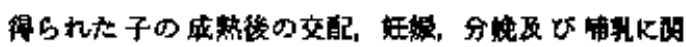

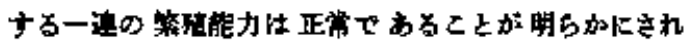
た.

日音会极, $50(12): 885-890,1979$ 